RESEARCH NOTE

\section{Kudoa thyrsithes (Myxozoa, Multivalvulida) Causing "Milky Condition" in the Musculature of Paralichthys adspersus (Neopterygii, Pleuronectiformes, (Paralichthyidae) from Chile}

\section{Raúl Castro R, Rodrigo Burgos}

Depto. Acuicultura, Facultad Recursos del Mar, Universidad de Antofagasta, Casilla 170, Antofagasta, Chile

Key words: Myxosporea - parasite - fish - flatfish lysis - Chile

The presence of protistans parasitic on Chilean marine fishes is poorly known. Only few studies of the presence and/or effects of myxosporidians on Chilean marine fishes exist in the literature, being those of M Moser and E Noble (1976 Can J Zool 54: 1535-1537) on Ceratomyxa, E Noble et al. (1976 in M Jayasri, G Hoffman Prot Abstract 6: 61-91) on Myxidium, and M Oliva (1982 Cienc Tec del Mar 6 : 45-51) on Myxobolus. There are no records of Kudoa spp. for the Chilean fishes. In South America, reports of the genus are also scarce, namely those of Kudoa scienae Terán, Llicán and Luque, 1990 and Kudoa peruvianus Mateo, 1972 (L Teran et al. 1990 Rev Iber Parasitol 50: 25-29) for the Peruvian coast, $K$. rosenbuschi (Gelormini, 1944) by N Sardella (1988 Parasitol al Día 12: 13-18) for the Argentinian waters, and the same species for the Brazilian coast by C Lima dos Santos and E do Valle Zogbi (1969 Rev Veter UFRRJ: 94-103). During the study of the parasitic fauna of Paralichthys adspersus, 16 specimens collected in Taltal $\left(25^{\circ} 22^{\prime} \mathrm{S}, 70^{\circ} 31^{\prime} \mathrm{W}\right)$ were examined. One of them, a female (length $=30 \mathrm{~cm}$, weight $=$ $250 \mathrm{~g}$ ), presented musculature soft to the touch. When dissected, the musculature depicted four whitish, emaciated areas (two for each side of the body) (Fig. 1). The tissue was observed under SEM, using the usual technics (R Castro, $\mathrm{H}$ Baeza 1991 Proc Biol Soc Wash 104: 613-619). The spores were drawn with the aid of a camera lucida. The analisis determined the presence of mature and developing spores of myxozoan. According to the number of valves, polar capsules and the presence of a large polar capsules, one small and two of median, and the size of the spores, this protozoan was identified as Kudoa thyrsites (Gilchrist,1924) (Fig.2).

This parasite is known from different oceans and in distinct hosts fishes in the natural environment, as well as in captivity. It does not produce cysts but causes liquefaction of the muscles, as verified for Thyrsithes atun (Euphrasen,1791), Merluccius capensis Castelnau,1861, Zeus faber Linné,1758 (Z Kabata, DJ Whitaker 1981 Can J Zool 59: 2085-2091), giving it the "milky condition" or the gelatinous "jelly flesh" aspect (JS Langdon et al. 1992 J Fish Disease 15: 459-471).

It has been demonstrated that infection of muscle by certain species of Kudoa can produce a slow necrosis, without major damage to living fishes, but promoting liquefaction of the musculature post-mortem, as observed for P. adspersus.

In infected fishes, the muscles changes texture, resulting in a product of poor quality for the market (JA Dawssow et al. 1970 in JF Morado, AS Sparks, 1986 J Fish Dis 9: 445-455).

Kudoa thyrsites has among its host T. atun, Sardinops sagax neopilchardus (Steindachner), but it also infect other clupeids, engraulids, and salmonids (Z Kabata, DJ Whitaker 1989 Can J Zool 67: 341-342, JS Langdon et al. 1992 loc.cit.)

The infection by $K$. thyrsites on $P$. adspersus is the first record for the Chilean coast, as well as for all the South American coast. The knowledge of its biology and host-parasite relationships are needed, in order to avoid the infection and its effects on the fish in captivity, specially when $P$. adspersus has high expectatives of culture in Chile and Peru. 


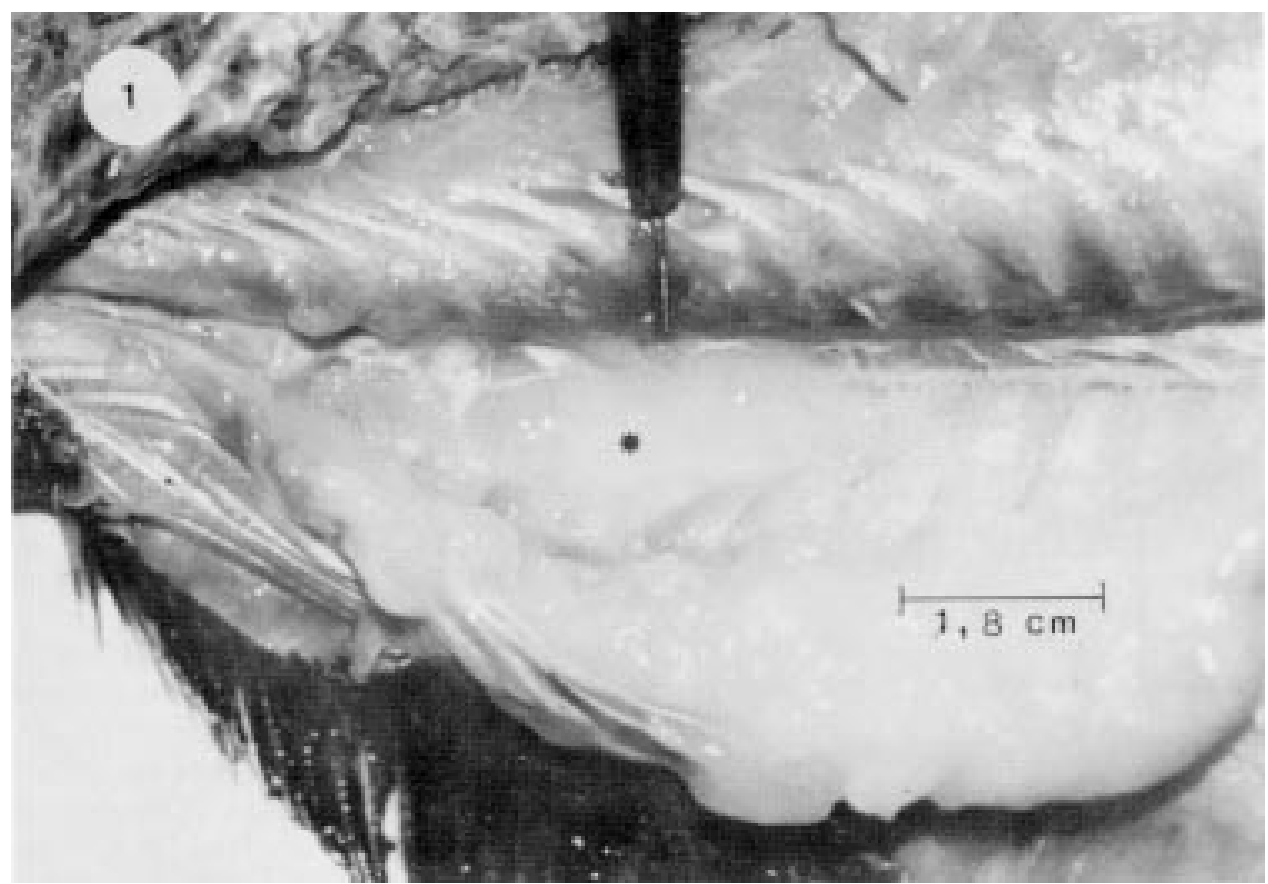

Fig. 1: musculature of Paralichthys adspersus. The asteriscus indicates an area presenting the milky condition produced by Kudoa thyrsithes from a frozen fish.

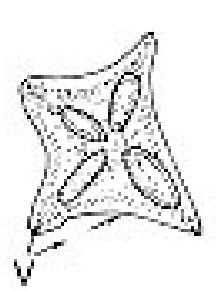

2
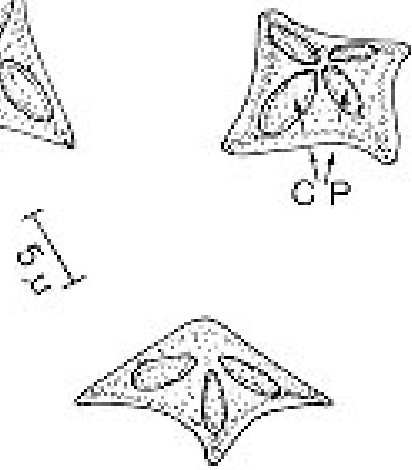

Fig.2: different views of spores of Kudoa thyrsithes observed under light microscope $(\mathrm{CP}=$ polar capsule, $\mathrm{V}=$ valve $)$. 